\title{
The Origin of Spirula spirula (Linne, 1758)
}

\author{
E. O. Heyfetz \\ Nachman mi Braslaw 14/3, Yaffo 6808998, Israel
}

\begin{abstract}
The article presents evidence regarding the origin of Spirula from spiral-shelled forms. The geological age of the species is revised from the Miocene to the Jurassic. The causes of the reorientation of the shell are elucidated. The mode of life of the mollusk is specified. The influence of the theory on facts perception is shown.
\end{abstract}

Key words: Buoyancy, chambers, distribution and geological age, guard, keels, mode of life, origin, orientation of the shell, phragmacone, proostracum, Spirula L.

\section{Introduction}

The spiral shell has been appeared many times during evolution of different shelled animals. There are many foraminifers, sessile bristleworm Spirorbis; gastropods; some bivalves (Exogirus, Gryphea, jewelbox clams, the rudist Toucasia, the extinct Pliocenian cockle Prosodacna and so on).

In cephalopods external planispiral shell appears independently in nautilids, ammonits and secondarily - in females of Argonauta. The results of these processes are on hand: shell compaction as adaptation to the greater maneuverability (at the expense of the speed). The other deal that on the way to this solution was temporary rejection from active mode of life - pass from the straight shell to the bent one and only afterwards - to the spiral one.

Even more problematic appears the postulated tendency of internal shell spiralization, whose clear example is spirula. The given article provides arguments in favor of the contrary standpoint. In contrast to lookthrough works, it represents no more than spread out proof of the correspondent thesis. For this reason the author stands just on the certain aspects, without pretending of the complete description of Spirula and familiar forms. Furthermore, in the course of arguments elaboration, those losing immediate

Corresponding author: E. O. Heyfetz, independent researcher, research field: paleontologyand hydrobiology. concern with the subject of work, were excluded.

In spite of such limitation a number of facts, unnoticed earlier, were found. It is natural that the signs, seeming negligible ones, acquire importance by another putting of the question, and in contrary: the consideration of question from a "conventional" standpoint could just obstruct or even to distort facts - that will be shown below. This moment is not ever taken into account in the scientific periodic, relying on authority of a specialist in such or another branch.

\section{Morphological}

\subsection{Spirula and Familiar Forms}

Spirula is a relict cephalopod with internal spiral shell. Currently belemnite-like Belemnoseina with bent chambered part of the shell (phragmocone) are accepted for the ancestral group.

Such a standpoint could not be based empirically: in contrast from belemnites, which are guiding fossils, belemnoseines are extremely rare, since their guard consists not from the calcite, but from less stable aragonite [1]. The other deal intuitive ground: presence of specific endocochlear appendages in belemnoseines, permitting their approach with ammonites, seems to be more important sign than spiral shape of shell, as was mentioned above, appearing independently in different mollusc groups and a number of other shelled animals. Correspondent 


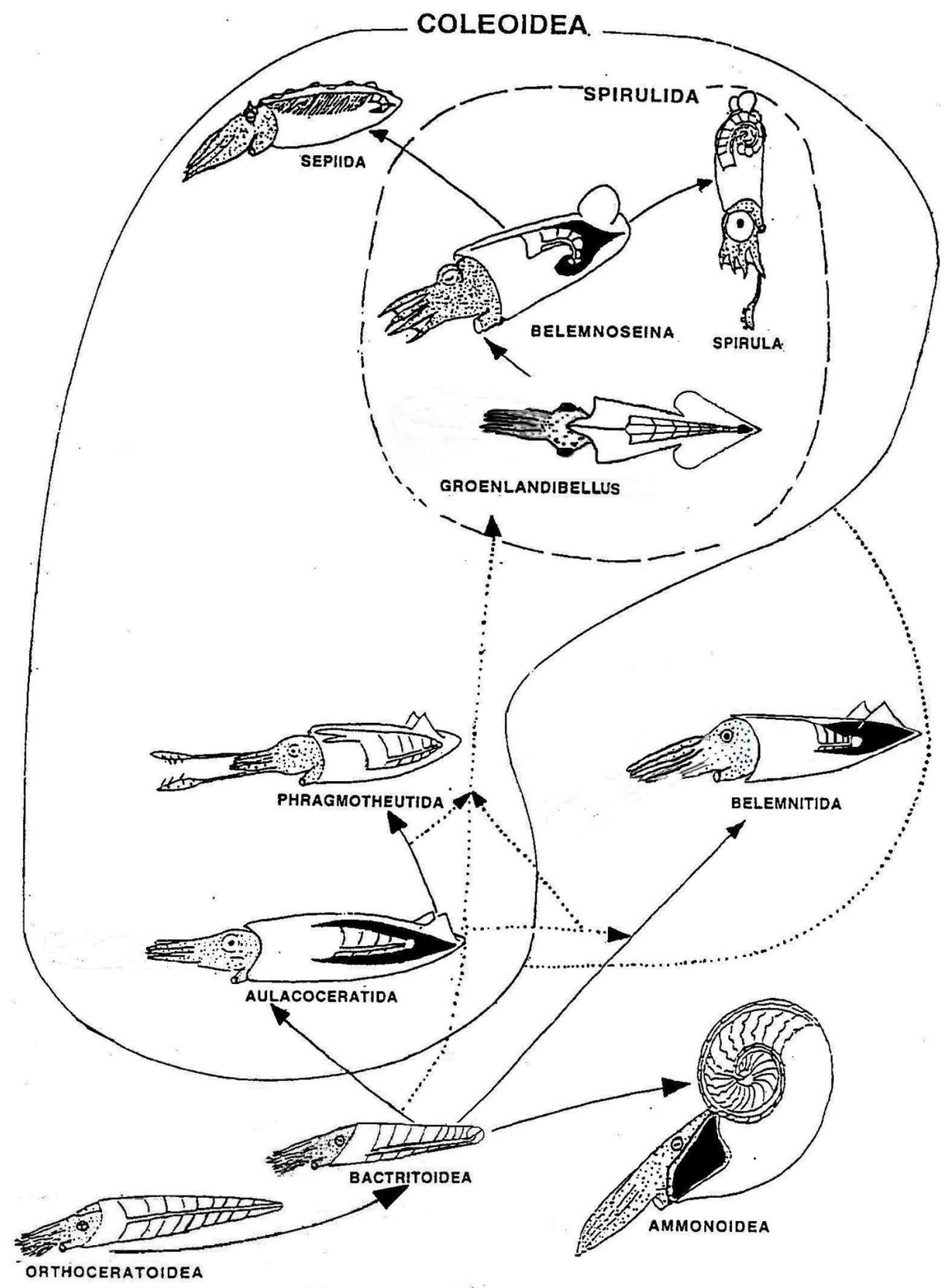

Fig. 1 The origin of Spirula due to the current version. 


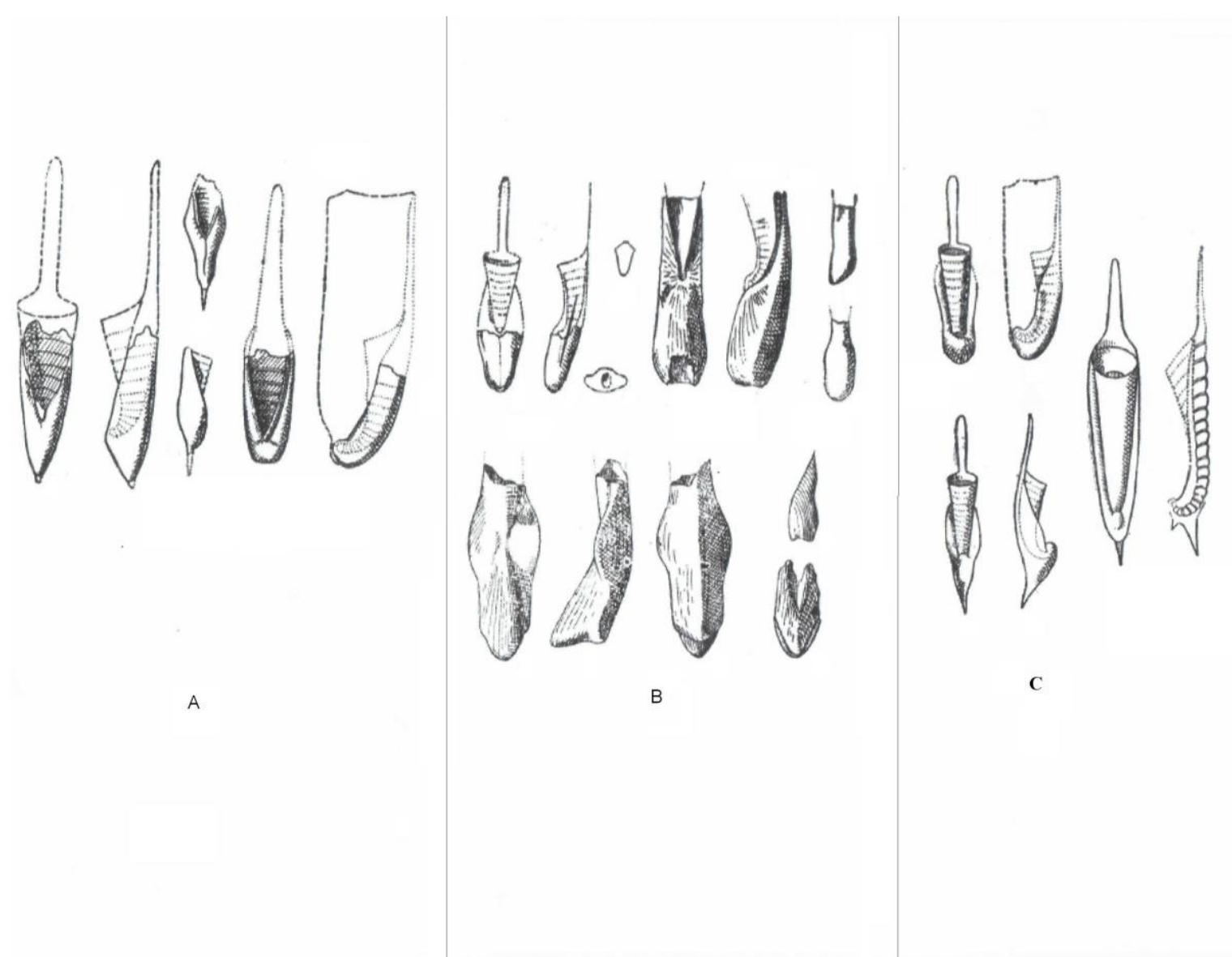

Fig. 2 The shells of the families Belopteridae (A) Belemnopsidae (B) and Spirulirostridae (C)—from the "fundamentals of paleontology.

version was defined also by opposite spiral orientation (see below).

Meanwhile, the normal tendency in the evolution of mollusc with the internal shell is its reduction up to its complete disappearance. Apparent exceptions, like guard, increasing material spending, decrease the working volume, i.e. the force of buoyancy of cephalopods' shell.

From the phragmocone function as such it was assumed that the process of internal shell spiralization was connected with development of passive buoyancy means. This is the classical version of the sepiae evolution [2] that obviously disregards with benthic mode of life of the majority of cuttlefishes.

In addition, from all the standpoints the most efficient mean to increase buoyancy would be the reduction of guard. First and foremost, it would give significant economy of material plus increase of the utile volume of the body cavity, and, in contrast, the production of phragmocone leads to insignificant increase of spending on shell building and to reduction of the utile volume of cavity, aggravated in the bent and spiral form by the bending of shell, whose alternative is a simple increase of the phragmocone diameter, like in belemnites. Meanwhile, the most bent forms of belemnoseines (e.g. Spirulirostra) possess a massive guard, reducing the assumed adaptation to zero.

Furthermore, guards of belemnoseines are sufficiently more changeable than the phragmocones (Fig. 2).

Since natural selection preserves only favorable changes, the guard would reflect evolutional tendency in the first turn. Meanwhile, as was said above, in the boundaries of suborder of Belemnoseina the guard does not show inclination to reduction. In such a way, 
the conclusion about belemnoseines' shell spiralization does not correspond both with relative variability of its parts, and with needs of the molluscs.

Both absence of any traces of guard and protoconch in Spirula are not evident in favor of the accepted version. Questions about their traces were asked repeatedly. Both Naef and Bruun emphasize that the juvenile Spirula completely lacks any traces of protoconch [2, 3]. Chun in after consideration of lightful organ of Spirula initially accepted it for vestigial guard [4]. Later he established the real function of the organ that was interpreted before as an adheasing disc. Warnke and Boletzky (2009) accept for the remnant of guard a thin membrane, developing on the ventral (i.e., anti-guard) side of initial chambers of Spirula shell.

Bizikov elaborates the theoretical grounding of the current version. The author dwells on the question of coleoids' origin from the spiral forms, and solves it negatively: "...Among the most ancient coleoid there are no one spirally coiled form. The impossibility of the coleoid origin from spirally coiled forms may be reinforced by logical arguments. Proostracum - straight supportive structure, commeasurable by the length with the body-would not appear in animals with spirally coiled shell" [5].

The spread objection as such is the evident about importance of the problem. The other deal, how probative the arguments mentioned are.

The internal shell bending in familiars of Spirula Bizikov considers as a juvenile adaptation to planctonic mode of life [5].

To this argument the mentioned contradiction between the function of guard and phragmocone is applied. The robust capitulum, enveloping the first phragmocone chambers from the ventral side (Fig. 3) is evident that the guard formation even preceded the phragmocone bending.

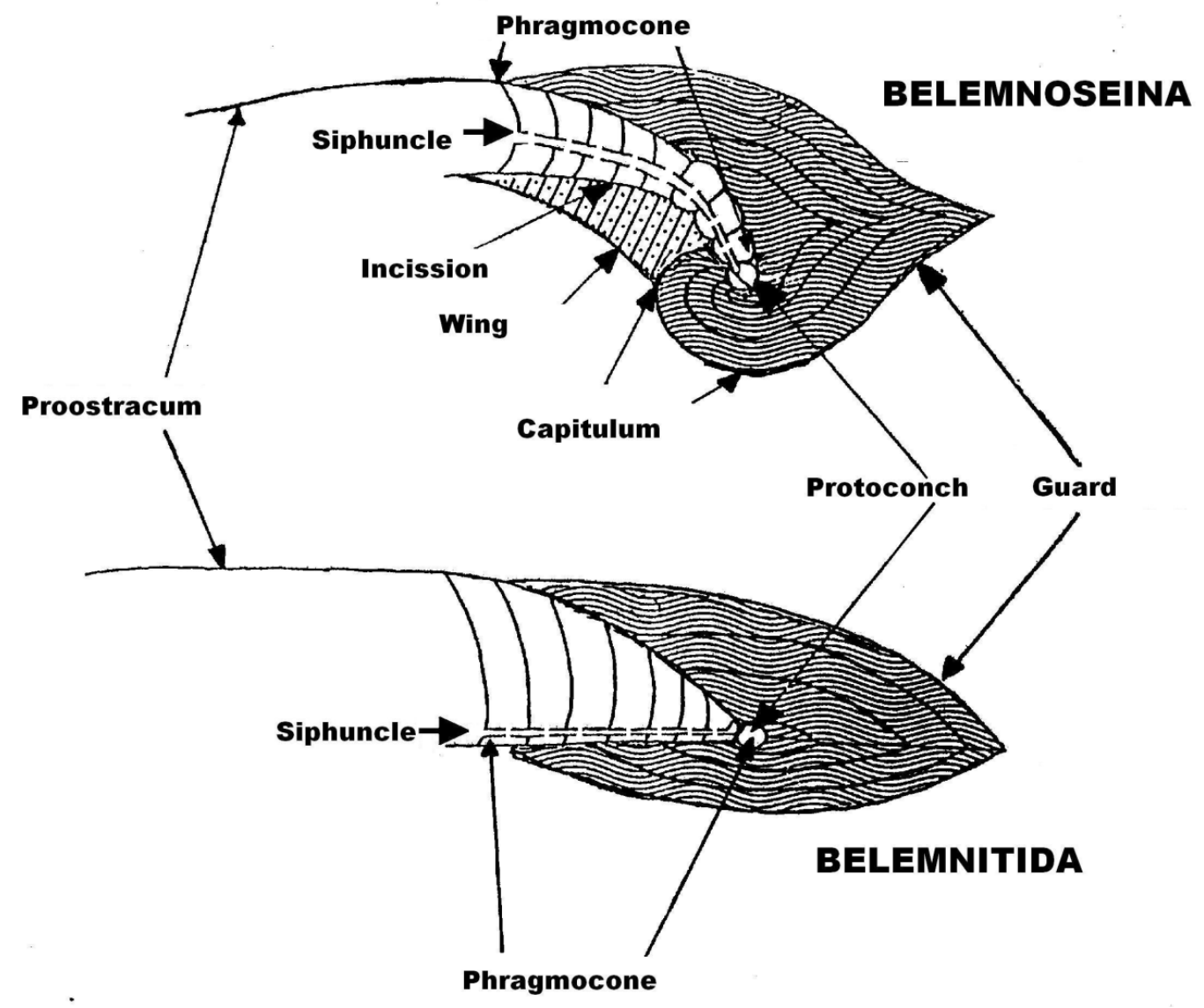

Fig. 3 The comparative shell morphology of Belemnitida and Belemnoseina. 


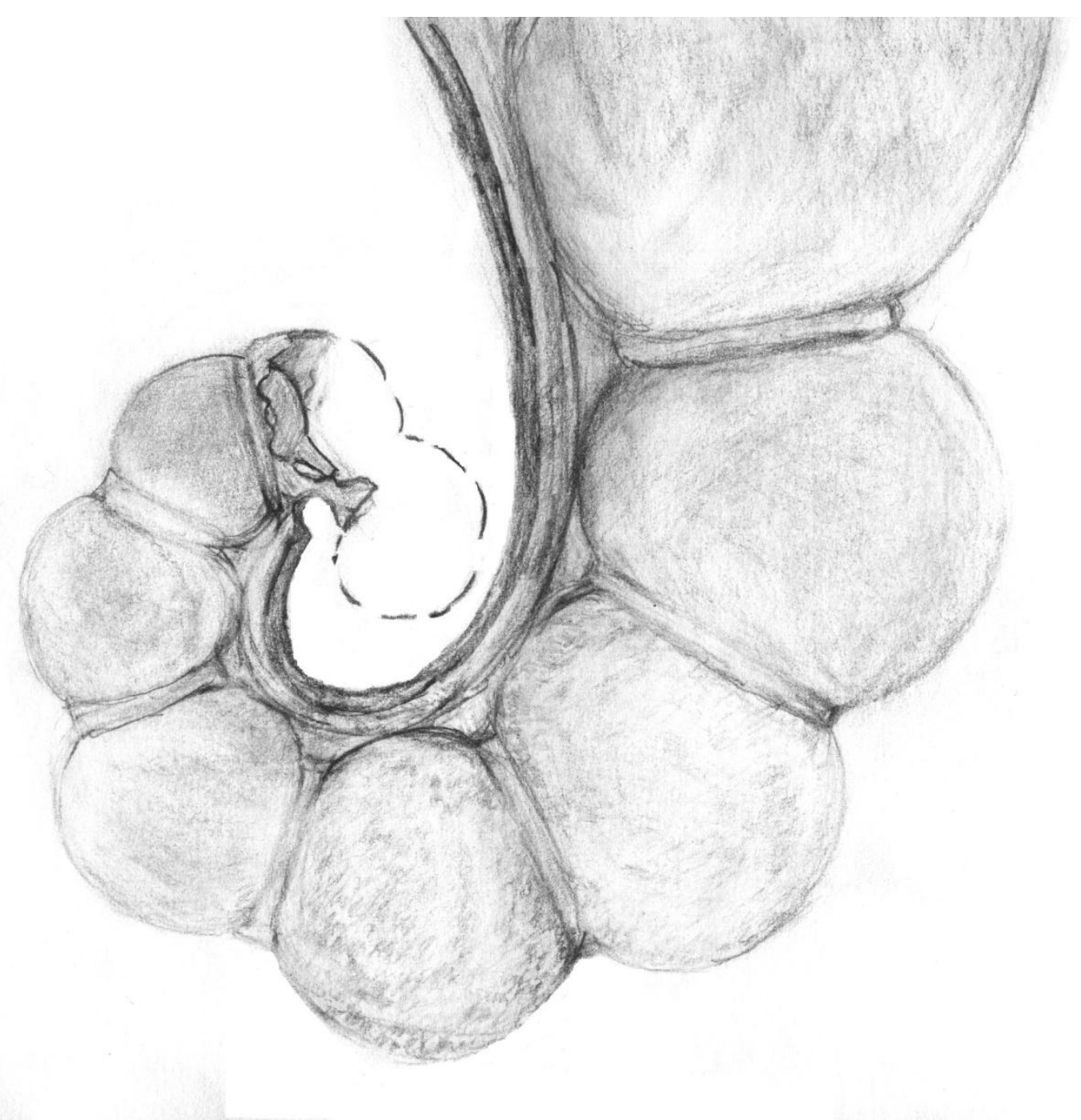

Fig. 4 The pair of keels on the juvenile whorls of the shell of Spirula (drawn from the object).

In the process of further shell growth the mantle sack, stretched on the phragmocone, lost the contact with its concave part and ceased to produce the guard on the ventral side (Figs. 2 and 3) - in contrast to that of belemnites.

The given peculiarity is preserved also in belemnoseines with straighten shell and their descendants, true cuttlefishes, where bending of phragmocone could not be obstacle for guards' development. This suggests that the straighten forms originated from the bent ones, and not on the contrary.

Correspondingly, both absence of specific appendages, and the spiral shape of shell are interpreted as the evidence of neothenic origin of the mollusc [5].
Such a suggestion permits to look on the facts more closely. Let us consider the shell, whose juvenile bubble-like chambers differ so sharply from barrel-like adult ones. On the internal (e.g. anti-guard) side of the juvenile whorl there is a pair of keels with furrow between them (like runners). Externally it resembles siphuncle, nevertheless, considering sections either samples with broken chambers it may be easily ascertain that the given formations are completely independent (Fig. 4).

In contrast to the guard of belemnoseines and sepiids, that is no more than overflow, the keels are clearly separated from the phragmocone. Appearing on the 2-nd chamber after protoconch they are smoothen towards 12 -th, reaching $0.3 \mathrm{~mm}$ in height. 


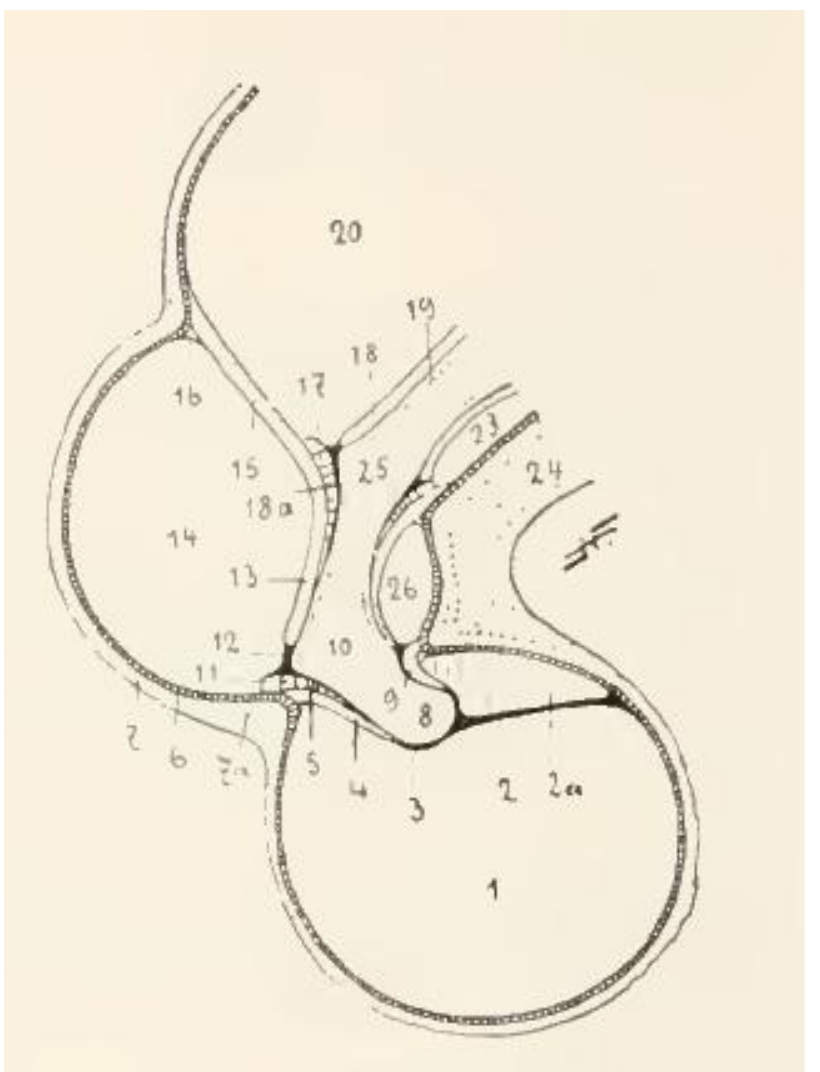

Fig. 5 Cross-section of the juvenile whorl. 24-ventral rib. From 2.

Due to their position and geometrically correct shape, they represent a kind of sheath that enveloped external part of the previous whorl.

The given structure was not described in details - that may be explained by its small size and "obscure significance". Naef restricts himself by mentioning of ventral rib of periostracum on the juvenile part of the shell [2], putting the drawing of first three chambers' section, but with no detail description of the formation.

Sometimes between the ventral sides of the protoconch and the following chamber thin membrane is preserved. It was described by Branco, 1880 and Appelöf, 1893 and currently it was re-discovered by Warnke and Boletzky. The authors assume that just it was described by Naef as the "rib". As was mentioned before, the attention to this structure is explained by its interpretation as a trace of guard [6]. It is likewise that the membrane represents a residual contact of the first whorls, and the rib, described by
Naef - combination of membrane with keels.

In such a way, the internal side of whorls, formerly contacting with previous ones, bears a whole number of evidences of its past significance, vividly showing that Spirula comes not from forms not with bent, but with tightly spiral shell.

\subsection{The Ammonite Features of Spirula}

A whole number of signs closing Spirula with ectocochlear molluscs are overlooked when it is considered from the standpoint of the current version.

Thus, the internal shell of Spirula is not inscribed in the contours of body, but is projected out on both ventral and dorsal sides of the body. I.e., its diameter together with covering skin is greater than that of the body. Frequently shell breaches the skin and comes out.

In the case of emergency Spirula retracts its head with extremities in the mantle that is closed by mantle valves (Fig. 7). 


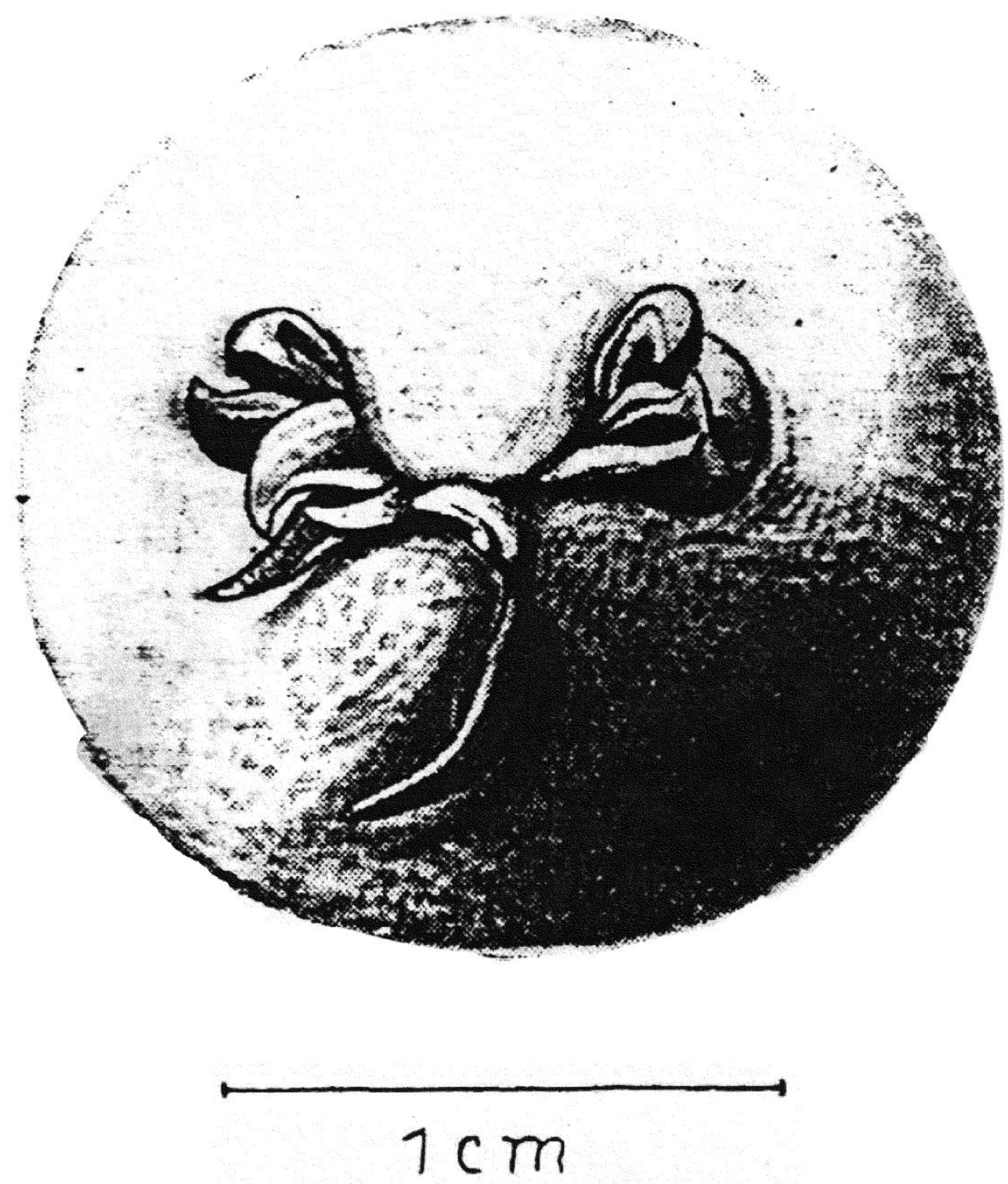

Fig. 6 Spirula, retracted the head, front view (from Bruun).

It is in order to remember here classical reconstruction of Trauth, due to which ammonites closed the shell aperture not by head lobe (as nautilids do), but with mantle operculum, complete (anaptichum) or valved (aptychi). The elongated living chamber of ammonits evidents is in favor of such a conclusion. By carnivorous mode of life it corresponded to developed tentacles. In the retracted stage head was in the depth of shell and was not able to close the aperture.

Such a picture rejected Schindewolf on a single argumentum that mantle cannot synthesize simultaneously aragonitic shell and calcitic operculum $^{3}$ [7]. Aptychi and anaptichi were interpreted as jaws of ammonites that contradict both to the shape correspondence of these formations and aperture and findings of typical cephalopod jaws in the same specimens [2]. Spirula provides an additional 
argument in favor of the classic version, and the letter confirms the ammonite origin of Spirula.

\subsection{Shell Orientation}

One of the most important arguments against the affinity of ammonits and Spirula is the opposite orientation of the spiral. In the former it is pointed from the stomach, in the second on it (exo- and endogastric whorls, correspondingly). Furthermore, the later orientation is similar with that of belemnites whose dorsal margin of shell was longer than the ventral one.

Naef writes: "Hand by hand very strong ventral curving of phragmocones goes, the penetration of belemnoid in the body of animal proceeded up to impossible degree" [2].

Jeletzky, the supporter of "ammonoid" version, indicates: "The presence of /protoconch features/ suggests closer relations /of sepiids/ to the Ammonitida (sic!) than to any other ectocochlian order but derivation of the Sepiida from the Ammonitida is ruled out by the opposite direction of coiling (or curving) of their shells" [10].

In such a way, it seems improbable that the complete spiral of the shell suddenly changed orientation $^{4}$, and not developed gradually in independent way, as a result of phragmocone bending, opposite to that of ectocochlear forms.

Nevertheless, coiling of the internal shell appears even more problematic. To all appearance, the orientation took place, and its causes must be investigated.

It may be remarked, first and foremost, that the shell orientation in typical ammonites and current Nautilus is defined not by a physiology, nor by a whim of mollusc, but rather, by buoyancy distribution. The same is right for endocochlear forms ${ }^{5}$.

Let us consider that the ancestor of Spirula, which swimmed in the horizontal position, possessed, like ammonites, by a shell with exogastric (pointed on the back) whorl.

The adaptation to the more even distribution of buoyancy became shell's uncoiling with simultaneous shift of the great diameter along the body axis (Fig. 7A). As a result, the former center of buoyancy that situated at the top of the external shell was shifted at $90^{\circ}$ downwards, i.e., towards the aboral end of animal. Furthermore, because instead of ectocochlear forms the body of the mollusc did not loaded the living chamber, the center of buoyancy has to pass additional shift downwards, at the direction to the apperture (Fig. 7A).
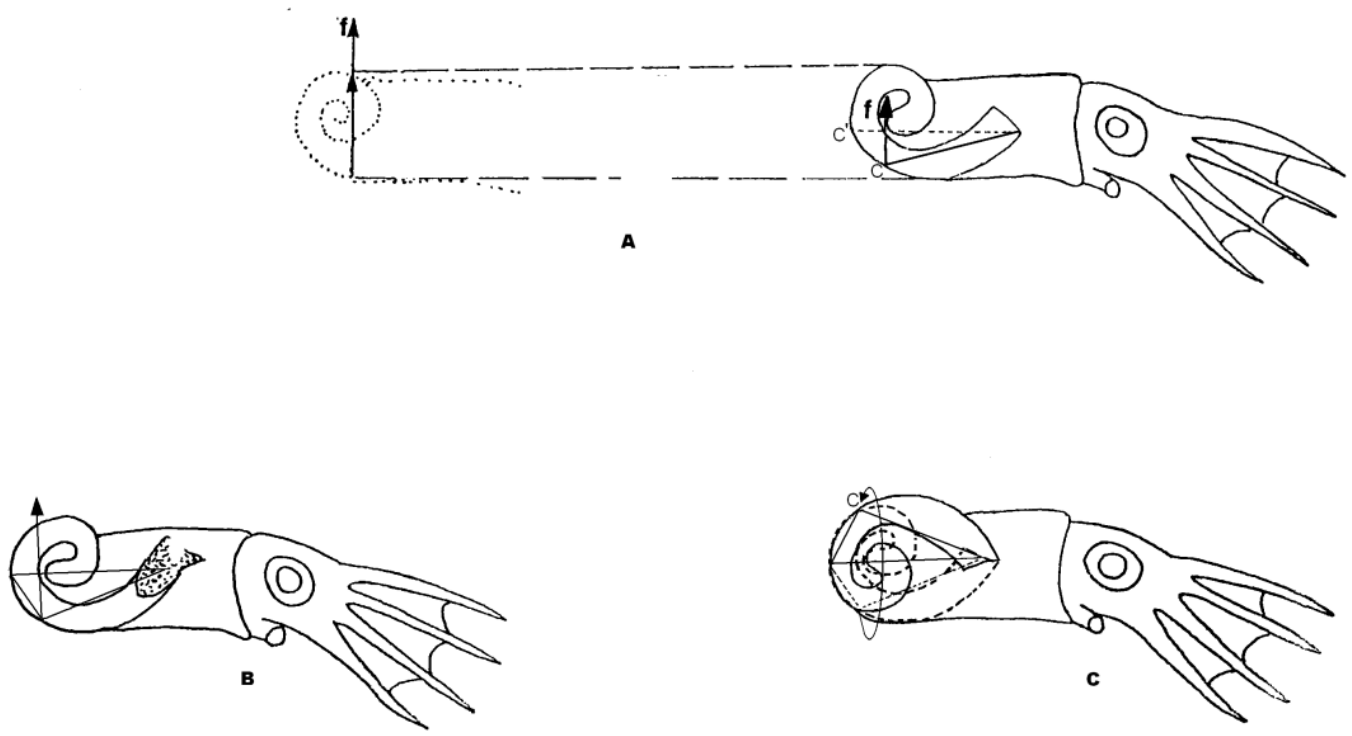

Fig. 7 Re-orientation of shell in Spirula ancestry. 
Fig. 7B shows the buoyancy distribution in the spiral shell before and after the reorientation. It is necessary to take into account, however that the shell of Spirula, though is not attached to the mantle sack walls, newerthelss is accompased by the firm cartilage [5], preventing shell oscillations during change of an animal course.

Thus, the overturn could happen before the complete formation of the whorl-or of the quite strong cartilagious capsule.

The alteration of the shell position in the given case is connected not with the natural selection, but rather, with the direct influence of mechanical factors. The other deal is preservation of the correct spiral by the point of growth detorsion. The evident about the later process is the position of siphon. It is found, like in typical ammonites near the ventral margin of the shell, but, because of the reorientation and detorsion near the inner side of whorl - not near the outer one, as in ammonites. Perhaps, the detorsion proceeded quite a long time; correspondent sides of mantle altered proportion of the shell synthesis rate, and the spiral preserved the former direction. The analogous examples are the gastropods that turn the shell during the metamorphosis in the more pleasant position. In Prosobranch snails (the group of Streptoneura) the visceral sac is torsed, and nervous stems are crossed (hence the name). In opistobranch and lung snails (the group of Ethyneura) such a torsion disappears completely by preservation of the shell orientation.

\section{Ecological}

\subsection{Definition of the Geological Age of Spirula}

The fossil remnants of Spirula were found in Miocene, i.e. sufficiently later after extinction of the typical ammonites. It is clear that its shell, thin and devoted of the appendages, have the least chance to be preserved than belemnoseines (as were said above, rare fossils), found a little bit earlier, in Eocene. I.e. the fossil shells of Spirula may be evident only that the mollusc appeared not hereafter the Miocene.

As regards to the current distribution of Spirula, yet Naef supposed that it is distributed in all open warm seas of the world ocean [2]. This viewpoint is shared currently, despite significant correction, introduced by expeditions of Bruun. Perhaps just an inattention to the data that seemed to be collateral, took place. Nevertheless, they permit to establish the age of Spirula more exactly than fossil remnants.

It should be mentioned that the correspondent division in the account of Bruun is called "Geographical distribution", not, let us say, "Places of catching" that imposes greater responsibility, in particular, relating the negative result. Here we must rely on conscientiousness of the expeditions that is still the most authoritative source.

As regards to the positive results, whereas expeditions of "Challenger" (1872-1876), "Blake" (1877-1886), "Princesse Alice" (1886-1922), "Valdivia" (1898-1899) catched one specimen, and "Michael Sars" (1904-1913) — eight individuals [3]—12 as whole; the using of net for different depth, aimed for the given aim, permitted the expeditions of Bruun on the vessels "Thor" (1909) and Dana to catch 193 specimen in different areas of the world ocean. By this the expedition of "Thor" catched only one individual. The expedition of "Dana", 1920-1923; 1921-1922-1995; 1928-1930-1933 animals, and the expedition of 1931 - one individual again.

As may be seen from the map (Fig. 5), the area of Spirula is broken in tree parts.

In the Indo-Pacific the area embraces region of India and also - of Northern and Eastern Australia. Near the coast of the Indian ocean of Africa Spirula was not catched. The catches in the Pacific coasts of the America's were not made-besides the gulf of Panama (where abundant deep catches were) and the Marquese islands [3]. Correspondingly in the shell collection that I studied, a whole number of points in American coast belonged to Atlantics only (i.e.-in geographical order-Texas, Florida, Brazil, 


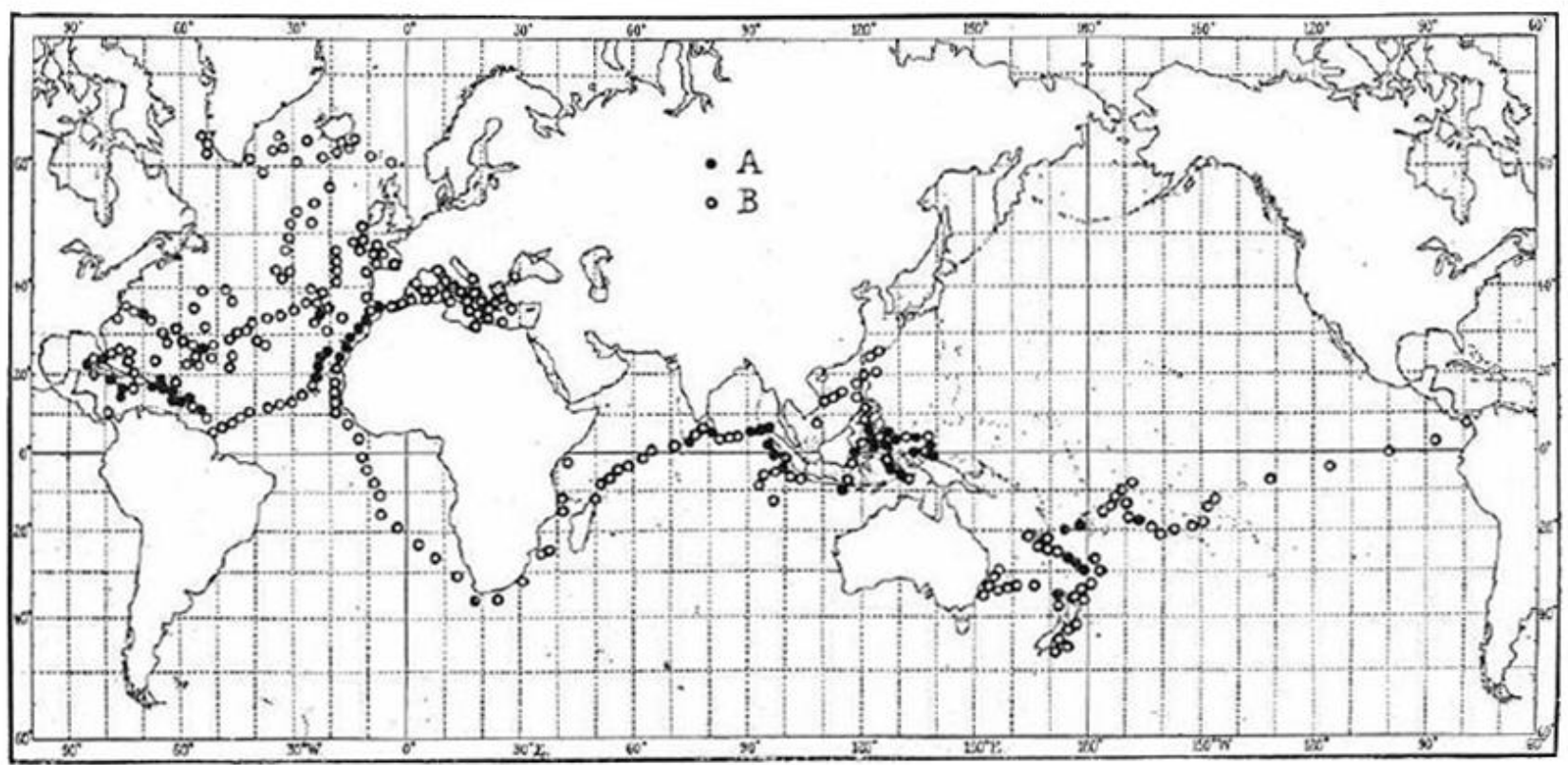

Fig. 8 Catches of Spirula by expeditions of Bruun: A—positive; B-negative results (from Bruun).

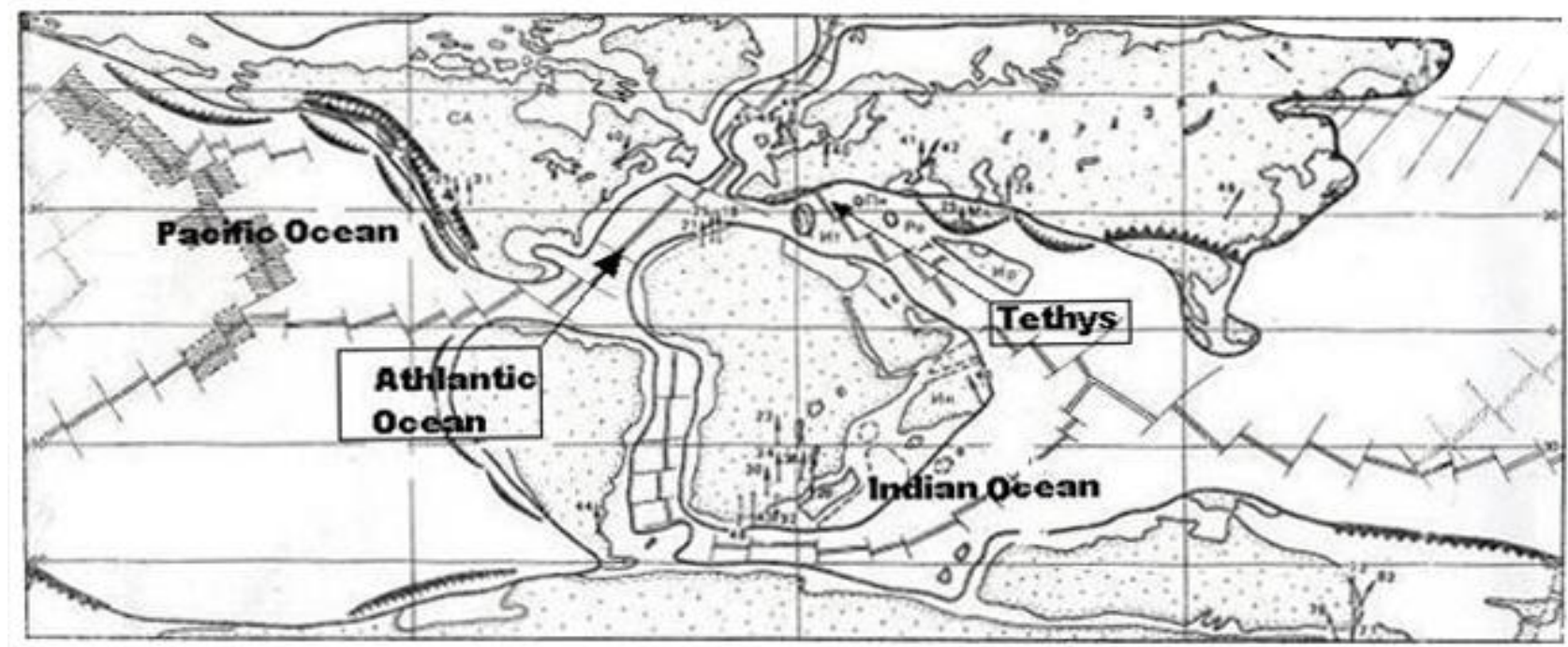

Fig. 9 The disposition of continents and oceans in the late Cretaceous (from Gorodnitsky, Sonnenstein and Mirkin).

Barbados), whereas shells from the Pacific coast of the continents were absent.

The Atlantic distribution of Spirula is of peculiar interest. Here it is found near the former mouth of Tethys - in the north part of the Atlantic coast of Africa (from Gibraltar gulf up to the middle of Mauritanian projection), and also in the correspondent huge excavation near the coasts of the Americas (Mexican gulf and Caribbean Sea). Though the northern part of
N. America has been separated from northern Europe in Miocene, the geometric correspondence between African and American areas permit to suggest that in the Atlantical region Spirula appeared before the final separation between the latter continents that proceeded in the late Jurassic [11]. Absence of populations outside of these regions is also remarkable. This may be connected, perhaps with changes of biocenosis in the process of the Atlantics formation. 
The absence of Spirula catches between the enclaves mentioned suggests that the center of Spirula origin was Tethys that connected the areas. The later ocean existed from the early Jurassic till Oligocene (Fig. 6).

In the later Oligocene Tethys ceased connection with the Indian Ocean [12], whereas connection with the Atlantics desisted in Maastricht, i.e. in the late Cretacious [13]. The remnant of Thetys, the ancient Mediterranean basin, was practically extinct in the Messinian crisis, i.e. in the late Miocene. At this time vanished the local population of Spirula, whose shells are found in the Miocene of the Italy [2]. The shallow-water Gibraltar gulf currently is the obstacle on the molluscan migration in the Mediterranean Sea.

In such a way the data of Bruun expeditions permit to suppose that Spirula are the relict of the Tethys, and its age is limited by the beginning and the end of Jurassic period of Mesozoan era.

\subsection{Function of the Lightful Organ}

In accordance with the version about development of the passive floating mean Spirula was treated repeatedly as bearing a passive mode of life. The morphology of lightful organ ${ }^{6}$, whose function appropriately is claimed to be mysterious, is evident against such a version.

Situating on the aboral side of the body, i.e. on the maximal distance from both eyes and tentacles it clearly does not serve illumination of the field of sight or as prey bait. It did not aim for defense against enemies (For this purpose some cephalopods ejaculate blinding luminous ink, whereas other ones disorient an enemy by illumination of stomach on the background of bright sky). The visibility of the lightful organ, found in the sucker-like pad, is too restricted.

It is likely that such an organ serves as the mean of distant signalization. In private, such a function assumed Broon.

In the vertical position, prescribed for animal, Spirula just will be unable to see the lightful organ of the other specimen, as the former is pointed upwards, whereas eyes look at side. Not too much improves the situation both the normal orientation. In this case Spirula would see deepened organ of the other individual only in the case, when their positions are mutually perpendicular, and eye of the given individual is found directly against the aboral end of the other one. It is sufficient to orientate itself by a ray of light. In favor of this assumption telescopic eyes, permitting to define weak changes of illumination degree.

Orientation of carnivorous animals (in private, tunes often attack the Spirula) by such a secret lantern is difficult. Thus, by enemy approach Spirula retracts in mantle and turns in vertical position, excluding the lightful organ from the field of carnivorous sight.

The aforesaid assumption may be checked by immediate observation.

In the theses, published in the materials of Malacological society, 2002, the lightful organ erroneously was called "luminophore". Anistratenko V. V. (Institute of zoology n. a. I. I. Schmalhausen NAS of Ukraine) mentioned that the accepted term is "photophore".

The correspondent roots came from Greek words " $\varphi \omega \varsigma$ " (genitive " $\varphi \omega \tau \circ \varsigma$ ") and Latin "lumen" that in both cases implies "light". Nevertheless the first root mostly relates to the light, coming from the external source: photoreceptor, photosynthesis, whereas the second one - to the light, emitted by organism itself: bioluminescence, luminescent organisms etc. In such a way, the term "photophore" appeared because of imperceptions of etymology hence it favors to confusion and encourages pedantism that gives preference of training before intelligence. I propose to correct the inexactness committed, and to replace the term "photophore" on "luminophore".

\subsection{The Mode of Life of Spirula}

It is considered that in the natural conditions Spirula swims in the vertical position head downwards, in accordance with the buoyancy distribution, hence, it 
Movements. Whether the specimens eaught were somewhat damaged of not they always ling ill vertical position, shell upmost, near the surface when brought into aquarias "molionless_ambiomllappearance lifeless" as Scinist (1922) states. He continues: "As a rulc, however, death was only simulated. Left t themselves, they wouli generally come to life, and soon begin breathing and other movements. The respiratos movements are effected by rhythmical contractions of the mantle, whereby water is forced out through tr funnel. As the mouth of this is turned towards the rear- $i$. e. upwards-the water flows up along the ventr: side of the mantle. This vertieally ascending current of water is easily noticeable. from its disturbing th frayed surface of the mantle.

Like other cuttle-lish, Spirula often makes swift jerky movements. dashing of suddenly in any direetion upwards, flownwards, or from side to side, These rushes were generally made by "backing", $i$, the anime moved with its hinder end forvard, having first "reversed" the funnel so as to tarn its opening forward toivards the hend, at the same time flattening the fins close into the posterior end, . . . . . . Less frequent Spirula was observed in the aquarium making a forward rush with its head to the front $-i . e$. without reversing the funnel. It is possible, however, that this latter mode of progress is the usual one-for example, when pursuit of prev.

Fig. 10 Text with description of Spirula movement in the aquarium (from Bruun).

is not able to make the normal movement. Such a conclusion disagrees with sociability of the mollusc, as like as possessing of the lightful organ, helping such a habit.

The current concept is based by immediate observations, provided by Danish scientist A. Bruun in the aquarium on the investigatory vessel "Dana" (1921-1922 and 1928-1930). Spirulas survived in the aquarium up to 48 hours. As was mentioned above, the catch formed 193 individuals.

Coming to conclusion about the active mode of life of Spirula, the author assumed that the current version is connected with non-critical relation to the conditions of observation. Really, Spirula was withdrawn from great depth, suffered temperature choke - refrigerator chamber on the vessel was absent, and the water warmed up to the temperature of air; the molluscs passed through a layer of stinging coelenterates, the external layer of mantle was damaged etc. [3].

Nevertheless, turning to the text I discovered that spirulas hanged downwards in the first minutes of the observation, before they completely recovered from choke. Afterwards the following description mentioned: "Like other cuttle-fish Spirula often makes swift jerky movements, dashing off suddenly in any direction: upwards, downwards, or from side to side.
These rushes were generally made by "backing", i.e. the animals moved with its hinder end forward, having first "reversed the funnel so as to torn its opening forward, towards the head, at the same time flattening the fins close into the posterior end/withstanding with the declining force of the shell buoyancy by funnel only/... Less frequently Spirula was observed in the aquarium making a forward rush with its head to the front" [3].

It is clear that the observations mentioned disagreed with well based version of the origin of Spirula. From the other side, the grounding of the expedition of Bruun leaves no doubts whatsoever. As a result the text was unwittingly conformed to the theory via missing of the "excessive" fragment.

Due to the description provided, Spirula nowhere near looks like passively floating animal with reduced muscles (like squid-bathyscaphe Cranchia). Being the perfect swimmer it is forced to overcome the surplus buoyancy of shell. In this situation the guard will not be the unnecessary ballast. Both its absence, like the spiral shape of the shell is primitive signs, inherited from ectocochlear ammonites.

Correspondingly, the passive defense of Spirula seems not the newest adaptation, but rather, the inheritance of ancestors, like the ability of motile and snappish soft-shelled turtles to retract the head into the shell. 
The mentioned prototypical features of Spirula permit to receive idea about appearance of ammonits that give a base to consider it as the specialized representative of the given subclass. At the same time Spirula possesses such newest adaptation as muscular mantle and fins. In such a way, it represents a transitional link between the most important stages of the cephalopod evolution.

As regards ammonites, they do not represent a blind branch, ending with Spirula. Cuttlefishes, octopuses and myopsid squid are closed to the latter, in contrast to the oegopsid squids that could be descendants of belemnite-like forms.

\section{Comments}

(1) In the given article possible evidences about origin of other Coleoidea from spiral forms (such as bending of the top of phragmocone in belemnite Pachytheuthis, ventral grow of belemnite guard, planispiral gladius top in recent squid Hystiotheutis) are not discussed. This subject requires a separate consideration.

(2) Starobogatov (1976) placed belemnite-like familiars of Spirula in suborder Belemnoseina [14]. The author of the current article keeps such a subdivision.

The subsequent discussion showed that the proposition of Starobogatov was not accepted by the current scientific society. The base of the current classification forms the system, proposed in the monography of Jeletzky, 1966. The family of Groenlandibellidae is affixed to the order of Sepiida, whereas the origin of the later from belemnites is rejected.

Groenlandibellids are characterized by narrow straight phragmocone and needle-shaped proostracum (Fig. 1). The guard is either vestigial (Groenlandibelus) whether absent (Naefia). The forms are similar with true belemnites. Thus, Groenlandibelus was described initially as the representative of the genus Belemnotheutis [15].
The base for both closing of Groenlandibellids with Sepiids, and rejection of belemnite origin serves the protoconch, plunged by thin prosiphon and blind encapsuled outgrow of the siphon, caecum [10]. In contrast, protoconch of Belemnitida, Aulacoceratida and Phragmotheutida is separated from phragmocone by secondary membrane - probably, larval adaptation for the buoyancy stabilization (Figs. 1 and 2).

"It is impossible to assume that the caecum and prosiphon could reappear in the Sepiida after having been completely lost by alleged belemnitid ancestors which there fore must be rooled out as root stock of Sepiida" [10].

Meanwhile the given sign is prototypical one, i.e. it characterizes not the degree of closeness of Groenlandibellids with sepiids, but the stage of "belemnitization" of both groups. In contrast to the indication of Jeletzky, the protoconch structure by itself cannot exclude the sepiid origin from primitive belemnite ancestors with the plunged protoconch.

The most important feature, however, is the guard morphology, because it does not restrict to one-time larval adaptation, but requires alteration of substances' exchange during all the life of the organism. The guard of Groenlandibelus, like that of belemnites is composed of calcite and possesses typical belemnite-like structure $[10,15]$. In such a way, signs of Groenlandibellid cannot form a base for separation of sepiids and belemnitids.

It is obvious the reduction to naught of the guard morphology as the criterion of closeness and, in contrary-hyperbolization of the protoconch significance with its carving out from the evolutional context (in private, factual rejection of possibility of closed protoconch evolving from a plunged one).

It seems that the cause of such an approach is rooted in the aspiration to close Spirula with ammonites (that requires its separation from the belemnite stock). Jeletzky emphasizes the affinity of sepiids and ammonites, but he is forced to deny direct origin because of the opposite whorl orientation. Furthermore, 


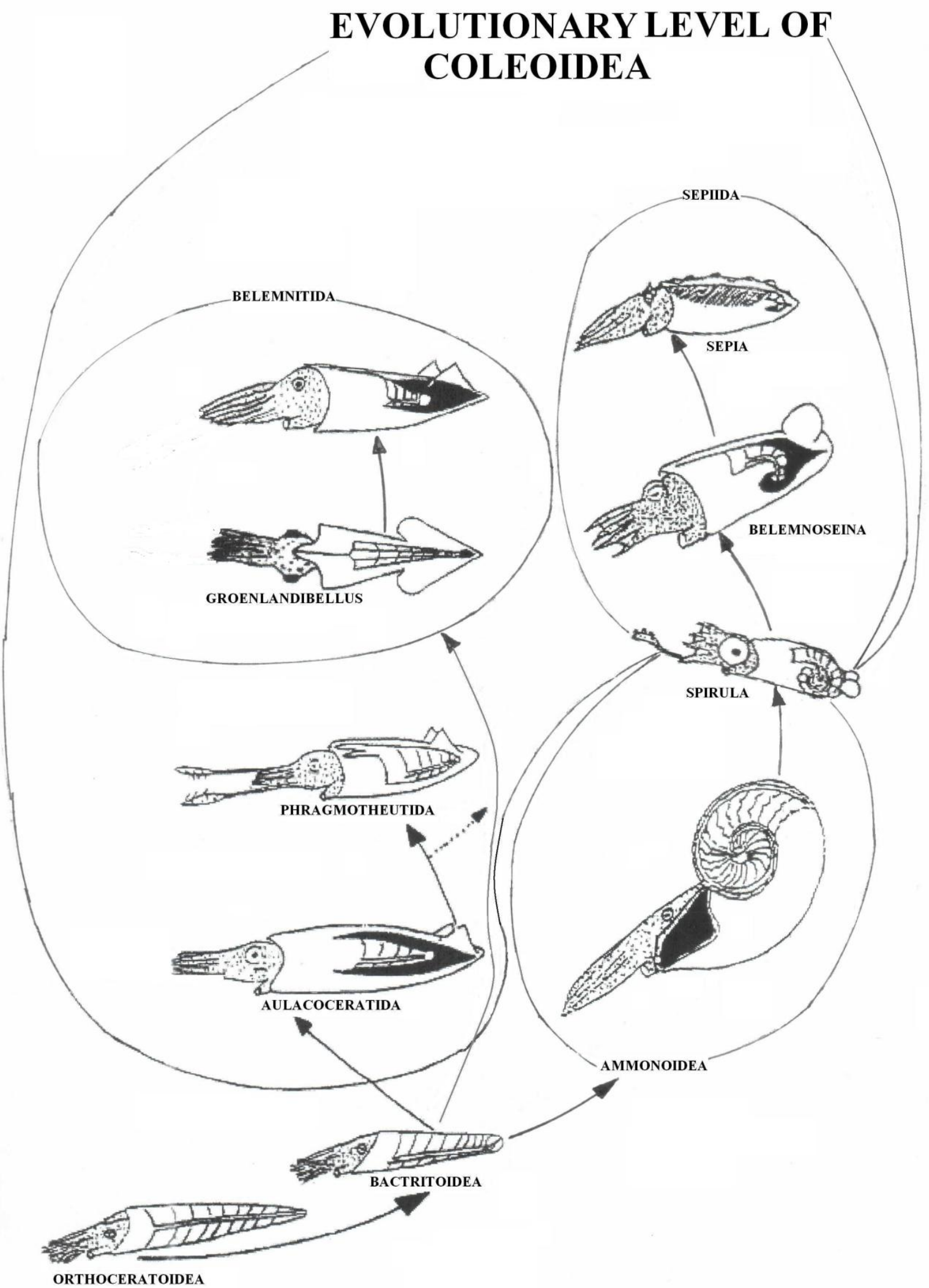

Fig. 11 Phylogeny of Spirula and related forms (according to the article). 
recognizing that the features of protoconch are prototypical one, thus, "can be inferred" in the assumed orthoconic ancestors of belemnites; Jeletzky, nevertheless, calls the "sepiid" protoconch "ammonite-like" [10].

The following step in this direction was made by Reitner and Engeser in 1982. The authors derive the order of Spirulida, including Spirula, groenlandibellids and belemnoseines (sensu Starobogatovi) immediately from Ammonoidea. The conclusion grounds not on the shell spiralization, since the Groenlandibellids are considered as the root group, but only on the morphology of protoconch mentioned.

The name of the order (about Heckel, 1896) converts so important sign, as spiralization of phragmocone in the pure formal denomination.

N. b. the correct bringing of the Spirula to ammonits supposes it placing in the separate order, more exactly, exclusion of belemnoseines and, furthermore, groenlandibellids from the order, bearing its name.

Both the superorder Spiruloidea, established by Bizikov, raises questions.

To this division are jointed recent deep-water squid order Chirotheutida because of their gladius similarity with phragmocone of groenlandibellids [5]; whereas the former pivotal group - the order Sepiida is excluded [5].

Similarity of cuttlefishes with Jurassic trachitheutids* on which Bizikov refers (ibid), if does not the result of convergency, then, in any case does not contradicts by sepiid origin from spirulids.

The evidence in favor of the latter is the plunged protoconch - the only base for groenlandibellids and belemnoseins' incorporation in the single order; characteristic for belemnoseines appendages (wings) and also-germinal (or vestigial) shell spiralization. It is necessary to remind also about argument of direct similarity of Spirulirostrina (Belemnoseina) with sepiids and Belosaepia (Sepia)—with belemnoseines, provided by representatives of the classic version [1, 2].

In such a way, the spread of the Spirula relationship at the expense of orthoconic (and/or planctonic) forms seems not well grounded, though fitted in one of the consistent schemes.

From the concepts mentioned it follows the importance to put the question about the internal spiral shell origin, and equally — of its proper solution.

*/The asterisk refers to previous comment as the subcomment/There are, in private, flattened, open on the ventral side phragmocone; papillose dorsal surface; weakly developed guard, hence, the similar mode of life.

(3) At the last time the version appeared, due to which lower jaw could perform as a shield, closing the shell aperture [17]. The given conclusion seems to be symptom of theoretization decline, when synthesis of facts is substituted by that of authorities' statements. For acceptance of such an exotic hypothesis more ponderable arguments are necessary than an impossibility of simultaneous synthesis of calcite operculum and aragonite shell by the same organ (mantle) that may be refuted by comparison with belemnites, whose mantle produced both, aragonitic phragmocone and calcitic guard.

(4) Indeed, it may be pointed to the turnover of the shell during gastropod metamorphosis. Reorientation may appear also as the result of exchange of the shell rate between the opposite its sides - in the quite common sinistral snails (Physa, Lanistes, Clausilidae etc.). The analogous examples in cephalopods were, perhaps, anomalous ectocochlear ammonites Climeniida (Devonian), whose siphuncle was positioned near the inner (not outer, as in typical ammonites) part of whorl. If this is the case, the upturned part, in contrast to that of snails, was not the shell (whose position was defined by buoyancy), but the ventral and the dorsal sides of the soft body.

(5) Correspondingly, the shell of belemnites was found in the most stable position. The longitudinal 

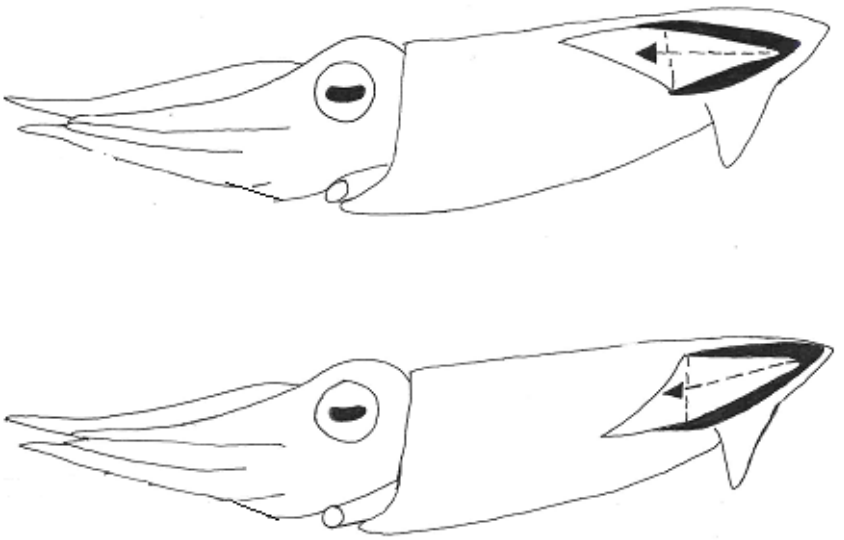

Fig. 12 Distribution of buoyancy in shells of belemnite-like cephalopods.

section of the phragmocone looks like rectangular triangle, whose hypothenuse is represented by the dorsal, and the greater, real cathetus - by the ventral side that lied, in average, near the horizontal position. The second, imaginary cathetus - is the line stretched from the extreme points of the sides - the diameter of the aperture. The center of buoyancy passed through bisectrix of the angle between the sides. The lines of hypotenuse, i.e. of the dorsal side and bisectrix were pointed obliquely upwards, whereas in the case of the opposite orientation-obliquely downwards. Shift of the line, connecting the centers of buoyancy, in the horizontal plane was impeded by both, position of the body and gravity of the guard.

\section{Acknowledgments}

I began to work on this article in Israel, where I spend few years. The valuable help put the members of Hebrew University of Jerusalem, Prof. J. Heller and doctor $\mathrm{H}$. Mienis and the member of Geological Survey of Israel Prof. Z. Lewy, Painter-animalist W. Fergusson consulted by figuration of drawings.

To all them I express my true thanks.

\section{References}

[1] Крымгольц Г. Я., Sepioidea//Основы палеонтологии. Моллюски - Головоногие, ч. ІІ,/ под ред. Орлова Ю. А., М.; Гостехиздат, 1958.-359 с-с. 162-168. (Krymholz G. Ya., Sepioidea//Fundamentals of paleontology. Molluscs - cephalopods, p. II/edited by Orlov Yu. A., Moscow, Gostekhizdat, 1958. p. 359. in Russian).

[2] Naef, A. 1922. Die Fossile Tintenfische, Verlag Gustav Fischer, Jena, p. 322.

[3] Bruun, A. 1943. The Biology of Spirula Spirula. Dana-Report, p. 44 Available at site: //rogov.zwz.ru/bruun,\%....ula.pdf.

[4] Chun, K. 1903. Aus den Tiefe des Weltmeeres, Jena, Fischer, $591 \mathrm{~s}$.

[5] Бизиков, А. В., Эволюция формы и функции раковины головоногих моллюсков подкласса Coleoidea, Автореферат диссертации на соискание ученой степени доктора биологических наук, М. 2008 - 52 с. Размещен на сайте (Bizikov A. V., Evolution of shape and functions of shell of cephalopod molluscs of the subclass of Coleoidea, author's abstract of dissertation for inception of scientific degree biological science doctor, Moscow 2008, p. 52, in Russian.

[6] Warnke, K. M., and Boletzky, S. V. 2009. "The 'Ventral Rib' of the Shell in Spirula (Cephalopoda, Coleoidea): A Cryptic Guard?" Berliner paläobiologische Abhandlungen 10 (11-11): 357-9. 
[7] Lehmann, U. 1982. The Ammonites. Their Life and Their Forms. Cambridge: Cambridge University Press, p. 466.

[8] Друщиц В. В., Догужаева Л. А. Аммониты под электронным микроскопом. М.; МГУ, 1981.-240 с. (Druschitz V. V., Doguzhayeva L. A. Ammonites under the electronic microscope, Moscow, editory of Moscow State University, 1981 p. 240. in Russian).

[9] Lewy, Z. 2000. "Nevertheless, Aptychi Are Ammonoid Opercular Plates, Geological Survey of Israel." Current Research (12): 155-8.

[10] Jeletzky, J. A. 1966. Comparative Morphology, Phyllogeny and Classification of Fossil Coleoidea, The University of Kansas publishers, p. 162.

[11] Городницкий, А. М., Зоненштайн Л. П., Мирлин Е. Г., Реконструкция положения материков в фанерозое, М. Наука, 1978. -121 с. (Gorodnitsky A. M., Zonenschtein L. P., Mirlin Ye. G., Reconstruction of the continents position in the Phanerozoe eon, Moscow, Nauka, 1978 p. 121 in Russian).

[12] Леонов Г. П., Историческая геология, М., МГУ 1956-363 c. (Leonov G. P., Historical geology, Moscow, editory of the Moscow State University 1956 p. 363, in Russian).
[13] Свиточ А. А., Сорохтин О. Г., Ушаков С. А., Палеогеография, М., Academia, 2004-448 c. (Switoch A. A., Sorokhtin O. G., Ushakov S. A., Paleogeography, Moscow, Academia, 2004 p. 448, in Russian).

[14] Старобогатов Я. И. 1976. Основные особенности филогении головоногих моллюсков и вопросы их системы. В сб.: Тез. Докл. Совещ. по пробл. «Основные проблемы систематики животных». М.; с. 17-22. (Starobogatov Ya. I. 1976 Main peculiarities of cephalopod mollusc phylogeny and questions of their system. In Transact: Thes. Rep. Counc. by Probl. "The main problems of animal systematics". Moscow; pp. 17-22.

[15] Birkelund, T., and Hansen, H. J. 1974. Shell Ultrastrucures of Some Maastrichtian Ammonoidea and Coleoidea and Their Taxonomic Implication. Munskgaard, København, pp. 34, + 15 plates.

[16] Reithner, J., and Engeser T. 1982. "Phylogenetic Trends in Phragmocone-Bearing Coleoids (Belemnomorpha)." Neues Jahrb. Geol. Paläont. 164: 156-62.

[17] Lehman, U., and Kulicki, C. 1990. "Double Function of Aptychi (Ammonoidea) as Jaw Elements and Opercula." Lethaia 23: 325-31. 